\title{
PENGARUH PEMBIAYAAN MODAL USAHA TERHADAP PENINGKATAN USAHA NASABAH DI KSPPS BMT NU JAWA TIMUR PADA MASYARAKAT MADURA
}

\author{
Nashar dan Moh. Fausi \\ Institut Agama Islam Negeri Madura \\ Email:nashargalis@gmail.com danmohfausi@stainpamekasan.ac.id
}

\begin{abstract}
Save and Credit Cooperatives of Syariah Financing BMT NU East Java is a bank that runs syariah principles. Differentiation is very important and must be owned by Islamic banks that have a strategy to retain customers who make credit by means of service excelent, mentoring and education, and emotional relations. The purpose of this study is knowing and analyze the effect of venture capital financing on the increase customer's business at KSPP Syariah BMT $N U$ East Java and for obtain empirical data on whether or not there is an influence of venture capital financing. This study use quantitative approach with analysis simple linear regression techniques to SPSS 20 aplicatrion. While testing the hypothesis using the t test calculation. The population in this study amounted to 35 customers. Samples use saturated or census samples. Data collection techniques using questionnaires. The results is first, the t test of business capital financing variable shows 0,000 smaller than a $(0,000<0.05)$. $t$ count $>t$ table (7.909> 1.68957). This means that venture capital financing has a significant effect on business improvement. Second, $R$ Square values obtained, amounting to 0.655 or $65.5 \%$. This means that $65.5 \%$ of the regression models in this study in explaining the dependent variable (Increased Effort), while the remaining $34.5 \%$ is influenced variables not account in the result.
\end{abstract}

Keywords: Funding, Startup Capital, Business Improvement, and Customer.

\begin{abstract}
Abstrak
Koperasi Simpan Pinjam Pembiayaan Syariah BMT NU Jawa Timur adalah bank yang menjalankan prinsip secara syariah. Diferensiasi yang sangat penting dan harus dimiliki oleh bank syariah yaitu mempunyai strategi untuk mempertahankan nasabah yang melakukan pinjaman dengan cara service excelent, pendampingan dan edukasi, dan emosional relasi. Tujuan penelitian ini adalah untuk mengetahui dan menganalisa pengaruh pembiayaan modal usaha terhadap peningkatan usaha nasabah di KSPP. Syariah BMT NU Jawa Timur, serta untuk memperoleh data emperis tentang ada tidaknya pengaruh pembiayaan modal usaha. Penelitian ini menggunakan pendekatan kuantitatif dengan teknik analisis regresi linier sederhana dengan bantuan alat analisis SPSS 20. Sedangkan uji hipotesis menggunakan perhitungan uji t. Populasi dalam penelitian ini berjumlah 35 nasabah. Sampel meggunakan sampel jenuh atau sensus. Teknik pengumpulan data menggunakan, kuesioner (angket). Hasil penelitian menunjukkan bahwa: pertama, dengan uji $t$ variabel pembiayaan modal usaha menunjukkan 0,000 lebih kecil dari a $(0,000<0,05)$. Nilai thitung $>$ ttabel (7,909 > 1,68957). Artinya pembiayaan modal usaha berpengaruh signifikan terhadap peningkatan usaha. Kedua, diperoleh nilai $R$ Square, sebesar 0,655 atau 65,5\%. Hal ini berarti sebesar 65,5\% model regresi pada penelitian ini dalam menerangkan variabel dependent (Peningkatan Usaha), sedangkan sisanya 34,5\% dipengaruhi oleh variabelvariabel yang tidak diperhitungkan dalam penelitian.
\end{abstract}

Kata Kunci: Pembiayaan, Modal Usaha, Peningkatan Usaha, and Nasabah. 


\section{PENDAHULUAN}

Manusia adalah makhluk hidup, karena untuk segala kebutuhan, baik dalam memenuhi kebutuhan konsumsi maupun menjalin hubungan dengan manusia. Salah satu cara untuk memenuhi kebutuhannya tersebut manusia memerlukan modal. Kebutuhan hidup seseorang bisa saja berupa barang atau jasa terkadang harus didapatkan dari orang lain, kelompok, industri atau semacamnya dengan cara membeli.

Salah satu cara yang bisa ditempuh untuk mendapatkan uang, yaitu meminjam uang kepada pihak lain, salah satunya kepada lembaga keuangan untuk meringankan beban seseorang dalam menjalankan sebuah usaha. Bank Syariah merupakan Bank yang menjalankan prinsip secara syariah. Artinya prinsip yang berdasarkan pada kaidah-kaidah keislaman. Islam merupakan agama yang sempurna, mengurusi semua hal dalam hidup manusia. Islam agama yang mampu menyeibangkan dunia dan akhirat, antara hablum minallah (hubungan dengan Allah) dan hablum minannas (hubungan sesama manusia (Bakhri, Leliya, \& Purnama, 2018).

Salah satu bentuk hubungan manusia dengan manusia adalah berkembangnya lembaga keuangan syariah. Secara alamiah di indonesia lembaga keuangan syariah saat ini mengalami beberapa peningkatan, untuk itu perusahaan harus mampu bersaing dengan perusahaan keuangan lain tentunya melalui jasa yang diberikan kepada nasabah.. Akan tetapi pada Bank Syariah aturan-aturan yang digunakan yaitu aturan yang secara islami sehingga tidak menyimpang dari ajaran islam.

Salah satu bentuk lembaga keuangan syariah yang berkembang yaitu Baitul Mall Wattanwil (BMT). Peran umum BMT menurut Soedarsono dalam Damayanti adalah melakukan pembinaan dan pendanaan yang berdasarkan sistem syariah. Yang menegaskan prinsip syariah dalam kehidupan ekonomi masyarakat, sebagai lembaga keuangan yang bersentuhan langsung dengan kehidupan masyarakat (Damayanti \& Herianingrum, 2014).

Kinerja yang dilakukan BMT relatif menyentuh para pedagang kecil dengan masalah keterbatasan modal. Salah satu kendala utama yang selalu dirasakan Masyarakat Madura dalam menjalakan usaha adalah dalam hal keterbatasan modal, banyak masyarakat yang menginginkan usahanya mengalami peningkatan. Dengan tersedianya modal yang cukup akan memungkinkan suatu usaha untuk dapat mempertahankan eksistensinya dan dapat menjalankan kegiatan usahanya dengan lancar.

Upaya lain yang dilakukan oleh BMT adalah berperan sebagaimana perbankan lainnya, yakni dengan mengumpulkan dana berbasis bisnis. BMT memiliki beberapa produk yaitu Produk Tabungan dan Produk Pembiayaan. Produk tabungan terdiri dari Mudharabah, Murabahah, Musyarakah, dan Qardul hasan dan lain-lain dengan menerapkan prinsip bagi hasil (Ridwan, 2006). Sedangkan produk Pembiayaan terdiri dari pembiayaan dengan jasa seikhlasnya ( $\mathrm{Al}$ Qardul Hasan), pembiayaan dengan pola penjualan barang (Murabahah), dan pembiayaan dengan pola bagi hasil (Mudharabah).

Koperasi Simpan Pinjam Pembiayaan (KSSP Syariah) BMT NU Jawa Timur Cabang Utama adalah lembaga yang beroperasi dengan prinsip syariah. Lokasinya yang berada di daerah pusat kegiatan masyarakat di seluruh Madura, menjadi sebuah perusahaan harus memiliki strategi dalam memberikan pembiayaan.

Para pedagang kecil sangat membutuhkan modal usaha agar usahannya yang dijalani bisa berkembang, dan mengalami peningkatan, atau perubahan. Peningkatan maksudnnya disini peningkatan dalam bidang usahanya, atau peningkatan dari segi pendapatan yang di terima dari sebelum mendapatkan pembiayaan maupun sesudah mendapatkan pembiayaan. Munculnya lembaga keuangan BMT ini 
untuk memberikan alternatif kepada masyarakat kalangan bawah dalam mendapatkan pembiayaan dengan kewajiban pengembalian yang cukup ringan (Ayogi \& Kurnia, 2015).

Berdasarkan wawancara yang dilakukan oleh peneliti dengan salah satu karyawan BMT NU Jawa Timur kebutuhan akan modal disana saat ini mengalami permintaan yang cukup tinggi, yang membutuhkan modal usaha itu kalangan pedangang kecil, petani, nelayan, dan PNS. Manyoritas yang melakukan pembiayaan modal usaha itu pedangang kecil dan petani agar usaha yang dijalani mengalami peningkatan dan perkembangan, disana mempunyai strategi untuk mempertahankan nasabah yang melakukan pinjaman dengan cara service excelent, pendampingan dan edukasi, dan emosional relasi. Dengan adanya BMT NU Jawa Timur, diharapkan mempunyai efek yang sangat kuat dalam menjalankan misinya dan dapat mengurangi ketergantungan pengusaha kecil dari lembaga-lembaga keuangan informal yang bunganya relatif lebih tinggi.

Pemberian pembiayaan yang diberikan oleh BMT NU Jawa Timur bisa membantu memandirikan ekonomi pengusaha kecil. Oleh karena itu Peneliti merasa penting melakukan analisis tengan seberapa besar pengaruh pembiayaan midal usaha terhadap Peningkatan Usaha Nasabah di KSPP Syariah BMT NU Jawa Timur pada Masyarakat Madura dan sekaligus melakukan analisis tentang seberapa besar kontribusi Pembiayaan Modal Usaha terhadap Peningkatan Usaha Nasabah di KSPP. Syariah BMT NU Jawa Timur pada Masyarakat Madura.

\section{LITERATURE REVIEW}

Untuk memperkaya referensi dan mendukung analisis maka diperlukan beberapa penelitian untuk menjadi sumber referensi, beberapa penelitian tentang pengaruh pembiayaan modal usaha terhadap peningkatan pendapatan sudah ditulis beberapa peneliti sebelumnya, seperti yang dilakukan oleh Erdah Litriani dan Leni Leviana pada penelitian pengaruh pembiayaan modal kerja terhadap pendapatan usaha pada PT. Bank Syariah Mandiri Kantor Cabang Simpang Patal Palembang dengan menggunakan pendekatan kuantitatif dihasilkan peneltian bahwa Penyediaan moda kerja sangat berpengaruh siginifikan terhadap peningkatan pendapatan usaha (Litriani \& Levianadah, 2017).

Pada Penelitian lain seperti Nurul Indayah, I Ketut Kirya dan I Wayan Suwendra yang dilakukan pada tahun 2014 dan membahas tentang Pengaruh Kredit Modal kerja Terhadap Pendapatan Bersih Usaha Kecil dan Menengah (UKM) Sektor Formal dengan menggunakan pendekatan kuantitatif kausal, menyebutkan bahwa kredit modal kerja berpengaruh positif dan signifikan terhadap peningkatan pendapatan bersih usaha dengan besarnya persentase pengaruh adalah sebesar 82,4\% (Inayah, Kirya, \& Suwendra, 2014).

Hal serupa juga disebutkan pada penelitian lain seperti Dica Suci Enggar Jati yang mengungkapan berdasarkan hasil penelitiannya pada tahun 2015 tentang Pengaruh Pemberian Kredit Modal Kerja Terhadap Tingkat Pendapatan Usaha Kecil Dan Menengah (UKM) Pada PT. Bank Pembiayaan Rakyat Syari'ah (BPRS) Margirizki Bahagia Bantul dengan metode pendekatan kuantitatif kausla menyebutkan bahwa kredit modal kerja secara positif dan signifikan mampu meningkatkan pendapatan UKM pada PT. BPRS Margirizki Bahagia Bantul dengan besar pengaruh adalah sebesar 30,3\% (Jati, 2015).

Berdasarkan pemaparan tersebut, belum ada satupun tinjauan secara khusus pengaruh pembiayaan modal usaha terhadap peningkatan usaha nasabah pada lembaga KPPS. BMT. Oleh karena itu, berbeda dengan objek penelitian terdahulu, penelitian kali ini akan difokuskan untuk mengetahui Pengaruh Pembiayaan Modal Usaha Terhadap Peningkatan Usaha Nasabah di KSPPS. BMT NU Jawa Timur 
pada Masyarakat Madura. Disinilah letak perbedaan penelitian ini dengan penelitian terdahulu diatas terutama terkait objek penelitian yang digunakan.

\section{METODE PENELITIAN}

Penelitian ini menggunakan pendekatan kuantitatif. Pendekatan, menurut Suryani dan Hendrayadi Penelitian Kuantitatif adalah merupakan penelitian yang menggunakan analisis data yang berbentuk numerik/angka (Suryani \& Hendryadi, 2018). Analisis data yang digunakan adalah dengan teknik analisis regresi linier sederhana dengan bantuan alat analisis SPSS 20. Sedangkan uji hipotesis menggunakan perhitungan uji t. Populasi dalam penelitian ini adalah pelaku usaha yang menjadi nasabah di KSPP Syariah BMT NU Jawa Timur.

Dari populasi tersebut kita ambil sampel dengan cara nonprobabilitas sampling, Dengan metode ini peneliti menginginkan sampel adalah orang yang dapat memeberikan informasi yang tepat dari fenomena yang terjadi, meberikan jawaban dan pemahaman yang lebih mendetail (Indrawan \& Yaniawati, 2017). Setelah melakukan beberapa fase tersebut maka peneliti menentukan jumlah sampel secara purposive dengan menempatkan batas yang dijadikan sampel adalah nasabah yang mendapatkan bantuan pembiayaan modal antara 25.000.000 sd. 50.000.000 dan sudah menjadi nasabah minimal 3 tahun. Atas dasar penentuan spesifik tersebut jumlah nasabah peneliti menemukan sebanyak 35 nasabah. Teknik pengumpulan data menggunakan, kuesioner (angket).

Variabel dalam penelitian ini adalah pembiayaan modal usaha $(X)$, dan Peningkatan pendapatan Usaha (Y). Pembiayan modal usaha adalah variabel independen, sementara peningkatan modal usaha adalah variabel dependen. Untuik mengetahui apakah ada hubungan diantara keduanya dilakukan analisis data statistik berdasarkan jawaban responden yang dikumpulkan melalui kuesioner.

\section{KONSEP DASAR}

\section{Pembiayaan Modal Usaha}

Pembiayaan modal kerja menurut (Antonio, 2001) adalah pembiayaan yang digunakan untuk memenuhi kebutuhan peningkatan produksi baik dari sisi jumlah hasil produksi (kuantiti) maupun dari sisi kualitas dan mutu produksi yang kemudian ditujukan untuk keperluan peningkatan utility of place dari suatu barang. Hal ini berarti penyaluran pembiayaan modal kerja termasuk usaha dapat memberikan peluang kepada nasabah untuk meningkatkan produksinya.

Selain itu, dalam (Muhammad, 2005) dijelaskan bahwa pemberian pembiayaan juga berupaya untuk memaksimalkan laba, karena dengan adanya dukungan dana yang cukup, maka setiap pelaku usaha termasuk nasabah akan dapat menghasilkan laba secara maksimal. Dalam pemberian modal kerja harus dilakukan melalui proses analisis pemberian pembiayaan modal kerja antara lain menurut Adiwarman (2013) adalah jenis usaha, skala usaha, tingkat kesulitan usaha yang dijalankan dan karakteristik transaksi dalam sektor usaha.

\section{Pendapatan Usaha}

Pendapatan diartikan sebagai upah/gaji yang merupakan balas jasa atas pekerjaan yang dilaksanakan dalam hubungan kerja dengan orang/instansi lain (sebagai karyawan yang dibayar). Sementara laba usaha merupakan hasil atas pekerjaan yang dilakukan sebagai pelaku usaha dalam mengambil keputusan terkait aktivitas produksi dan aktivitas lainnya, mengorganisir produksi, serta menanggung seluruh resiko atas keputusan dan pengelolaan tersebut sendiri (Malik \& Siringoringo, 2007) pendapatan usaha sangatlah penting karena dapat menentukan maju mundurnya suatu perusahaan. Agar pendapatan yang diterima dapat sesuai dengan yang diharapkan, maka pelaku usaha akan berusaha semaksimal mungkin (Litriani \& Levianadah, 2017). 


\section{PEMBAHASAN DAN DISKUSI}

\section{Hasil}

\section{Uji Regresi Linier Sederhana}

Regresi linier sederhana digunakan hanya untuk satu variabel bebas (independen) dan satu variabel terikat (dependen). Persamaan umum model regresi linier sederhana adalah sebagai berikut:

$$
Y=\alpha+b X
$$

Dari hasil analisis menggunakan program SPSS version 20 diperoleh hasil sebagai berikut:

Tabel 1 Hasil Analisis Regresi Linier

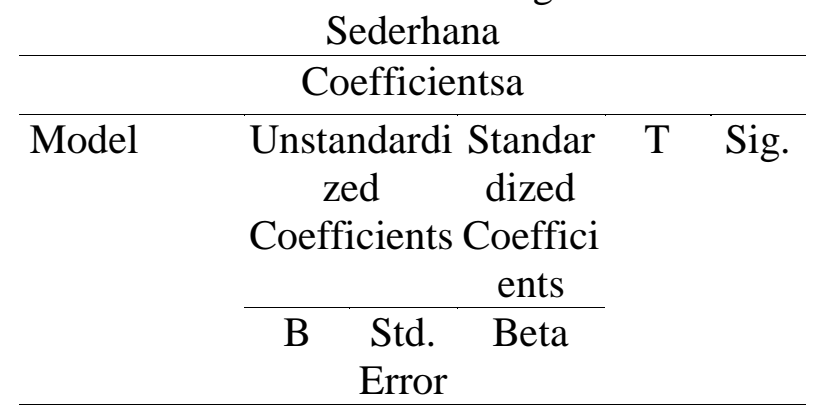

\begin{tabular}{lccc}
\hline (Consta & 22,50 & & \\
nt) & 6 & 6,708 & $3,355,002$ \\
\hline
\end{tabular}

1

Pembia

$\begin{array}{lllll}\text { yaan } & , 807 & , 102 & , 809 & 7,909,000 \\ \text { Modal } \\ \text { Usaha }\end{array}$

a. Dependent Variable: Peningkatan Usaha

Sumber: Output SPSS 20, 2018

Berdasarkan hasil analisis regresi linier sederhana pada tabel tersebut diperoleh koefisien variabel independent Pembiayaan Modal Usaha (X) =0,807 serta konstanta sebesar $=22,506$ sehingga model persamaan regresi yang diperoleh dalam penelitian ini adalah sebagai berikut:

$$
\mathrm{Y}=22,506+0,807 \mathrm{X}
$$

Dari model persamaan tersebut dapat diinterpretasikan sebagai berikut:

a. Konstanta sebesar 0,807 menyatakan bahwa jika Pembiayaan Modal Usaha tidak dipertimbangkan (bernilai 0), maka Peningkatan Usaha menggunakan produk pembiayaan Mudharabah di
BMT NU Jawa Timur adalah sebesar 0,807 .

b. Pada persamaan tersebut nilai koefisien regresi untuk variabel Pembiayaan Modal Usaha adalah positif. Hal ini berarti pengaruh variabel independen terhadap variabel dependen adalah positif. Sifat pengaruh yang positif menunjukkan bahwa apabila terjadi peningkatan terhadap variabel Peningkatan Usaha nasabah yang diberikan BMT NU Jawa Timur.

c. Nilai koefisien regresi variabel berarti Pembiayaan Modal Usaha 0,807 bahwa jika terjadi peningkatan sebesar satu satuan pada variabel tersebut maka peningkatan usaha nasabah yang menggunakan produk pembiayaan Mudharabah di BMT NU Jawa Timur meningkat sebesar 0,807 .

\section{Uji Signifikan Parsial (Uji T)}

Uji t digunakan untuk menunjukkan seberapa besar pengaruh variabel bebas (Pembiayaan Modal Usaha) terhadap variabel terikat (Peningkatan Usaha) dengan $a=0,05$. Hipotesis diuji dengan pengambilan keputusan sebagai berikut:

a. Jika $t_{\text {hitung }}<t_{\text {tabel, }}$, maka Ho diterima dan Ha ditolak (tidak ada pengaruh).

b. Jika $\mathrm{t}$ hitung $>\mathrm{t}$ tabel, maka Ho ditolak dan Ha diterima (ada pengaruh). 
Berikut hasil Uji $t$ dengan menggunakan SPSS versi 20:

Tabel 2 Hasil Uji t

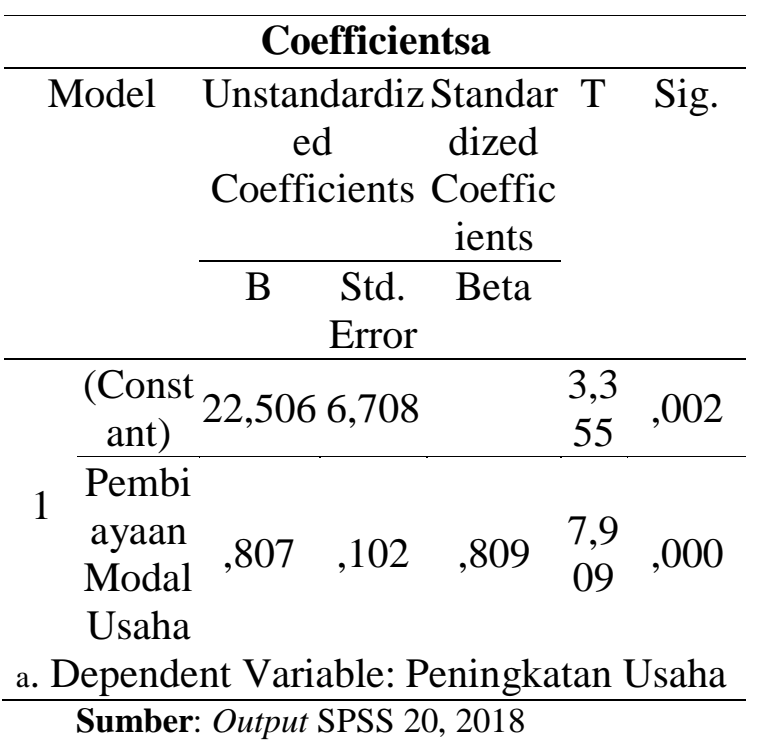

Dari tabel analisis uji t tersebut, hasil $t_{\text {hitung }}$ untuk variabel Pembiayaan Modal Usaha (X) diperoleh sebesar 7,909 dengan taraf signifikan 0,000 (lebih kecil dari signifikan 0,05) sedangkan $t_{\text {tabel }}$ sebesar 1,68957 , hal ini menunjukkan bahwa $t_{\text {hitung }}$ $>\mathrm{t}_{\text {tabel }}$ dan taraf signifikan sebesar 0,000 < 0,05 maka Ho ditolak, artinya Pembiayaan modal usaha mempunyai pengaruh signifikan terhadap peningkatan usaha nasabah.

\section{Koefisien Determinasi}

Koefisien determinasi $\left(\mathrm{R}^{2}\right)$ berfungsi untuk mengetahui sejauh mana atau seberapa besar kemampuan variabel bebas (Pembiayaan Modal Usaha) terhadap variabel terikat (Peningkatan Usaha). Berikut hasil koefisien determinasi $\left(\mathrm{R}^{2}\right)$ dengan menggunakan SPSS 20:
Tabel 3 Hasil Uji Koefisien Determinasi

\begin{tabular}{lcccc}
\hline \multicolumn{5}{c}{ Model Summary } \\
\hline Model & $\mathrm{R}$ & $\begin{array}{c}\mathrm{R} \\
\text { Square }\end{array}$ & $\begin{array}{c}\text { Adjuste } \\
\mathrm{d} \mathrm{R} \\
\text { Square }\end{array}$ & $\begin{array}{c}\text { Std. Error } \\
\text { of the } \\
\text { Estimate }\end{array}$ \\
\hline 1 &, $809^{\mathrm{a}}$ &, 655 &, 644 & 3,57003 \\
\hline
\end{tabular}

a. Predictors: (Constant), Pembiayaan

Modal Usaha

Sumber: Output SPSS 20, 2018

Hasil analisis data pada tabel di atas dapat diketahui bahwa besarnya $\mathrm{R}$ Square adalah 0,655 atau $65,5 \%$ yang berarti bahwa variabel independen (Pembiayaan Modal Usaha) mampu menjelaskan variabel dependen (Peningkatan Usaha) sebesar $65,5 \%$. Sedangkan sisanya $(100 \%-65,5 \%=$ $34,5 \%$ ) dipengaruhi oleh variabel-variabel lainnya yang tidak diperhitungkan dalam analisis penelitian ini.

\section{Hasil}

\section{Pembahasan Pertama}

Pengaruh Pembiayaan Modal Usaha terhadap Peningkatan Usaha Nasabah di KSPP. Syariah BMT NU Jawa Timur

Pembiayaan merupakan aktivitas bank syariah dalam menyalurkan dana kepada pihak lain selain bank berdasarkan prinsip syriah. Sedangkan modal kerja merupakan dana terikat dalam aset lancar perusahaan yang dibutuhkan untuk menjalankan aktivitas operasional perusahaan. Modal kerja yang perlu diperhatikan oleh perusahaan dalah modal kerja bersih yang dimiliki.

Pembiayaan kerja sama usaha yang disalurkan oleh KSPP. Syariah BMT NU Jawa Timur kepada nasabah merupakan investasi yang dilakukan KSPP. Syariah BMT NU Jawa Timur kepada nasabah. KSPP. Syariah BMT NU Jawa Timur mempercayai nasabah untuk menjalakan usahanya agar memperoleh keuntungan. Keuntungan atau hasil usaha nasabah atas usaha kerja sama ini akan dibagi antara KSPP. Syariah BMT NU Jawa Timur dan nasabah. Bagi hasil merupakan imbalan 
yang akan diterima oleh KSPP. Syariah BMT NU Jawa Timur atas pembiayaan kepada nasabah.

Pembiayaan kerja sama KSPP. Syariah BMT NU Jawa Timur merupakan aktivitas penyediaan dana atau tagihan yang dipersamakan dengan itu berupa kerja sama usaha antara KSPP. Syariah BMT NU Jawa Timur dan pihak yang membutuhkan modal untuk meningkatkan volume usahanya.

Pembiayaan modal kerja merupakan aktivitas KSPP. Syariah BMT NU Jawa Timur dalam menyalurkan dananya kepada nasabah yang membutuhkan dana. Pembiayaan sangat bermanfaat bagi KSPP. Syariah BMT NU Jawa Timur, nasabah dan juga bagi pemerintah.

Pembiayaan ini juga memberikan hasil yang cukup besar diantara pembiayaan dana lainnya. Pembiayaan modal kerja, bagi dunia usaha termasuk usaha kecil adalah sebagai sumber permodalan untuk menjaga kelangsungan atau meningkatkan usahanya.

Dengan adanya pembiayaan modal usaha bisa meringankan beban pengusaha kecil agar usaha yang dijalani tetap berkembang dan mengalami peningkatan usaha dalam bidang produksi dan penjualan.

Berdasarkan uji hipotesis yang dilakukan menunjukkan bahwa hasil koefisien regresi linier variabel independen (Pembiayaan Modal Usaha) yang bernilai positif yaitu sebesar 0,807 . Hal ini dapat diartikan bahwa pembiayaan modal usaha mempunyai hubungan yang positif terhadap peningkatan usaha nasabah, sehingga setiap terjadi peningkatan sebesar satu satuan pada pembiayaan modal usaha maka peningkatan usaha nasabah akan meningkat sebesar 0,807 .

Hasil hipotesis setelah dilakukan pengujian dengan menggunakan uji $t$ menunjukkan adanya pengaruh antara pembiayaan modal usaha terhadap peningkatan usaha. Hal ini dapat dibuktikan dari nilai koefisien korelasi variabel independen (Pembiayaan Modal Usaha) menunjukkan $t_{\text {hitung }} 7,909>t_{\text {tabel }} 1,68957$ dengan taraf signifikan sebesar $0,000<$
0,05 , serta nilai koefisien beta yang bernilai positif. Hal ini berarti bahwa pembiayaan modal usaha mempunyai pengaruh yang signifikan terhadap peningkatan usaha nasabah maka hipotesis Ho ditolak dan hipotesis $\mathrm{Ha}$ diterima karena $\mathrm{t}$ hitung lebih besar dari tabel.

Anggota merasakan bahwa peningkatan usaha di pengaruhi oleh pembiayaan modal usaha yang diberikan oleh KSPP. Syariah BMT NU Jawa Timur, anggota merasakan pelayanan pembiayaan yang diberikan oleh KSPP. Syariah BMT NU Jawa Timur begitu ramah baik dan selalu tersenyum, menjelaskan produkproduk yang ada di KSPP. Syariah BMT NU Jawa Timur dengan baik dan jelas, dan proses administrasi yang ada di KSPP. Syariah BMT NU Jawa Timur begitu cepat. Pembiayaan yang diberikan oleh KSPP. Syariah BMT NU Jawa Timur selalu tepat sasaran KSPP. Syariah BMT NU Jawa Timur memberikan pembiayaan untuk pembiayaan investasi, pembiayaan konsumtif dan pembiayaan modal kerja.

Pembiayaan di KSPP. Syariah BMT

NU Jawa Timur tepat sasaran salah satunya yaitu pembiayaan untuk usaha yang diberikan kepada anggota untuk meningkatkan volume usahanya, dan KSPP. Syariah BMT NU Jawa Timur dalam pemberian pembiayaan memperhatikan prinsip-prinsip pemberian pembiayaan dengan analisis $5 C$ selalu dilaksanakan agar pembiayaan bisa berjalan dengan lancar, yaitu ada Characther, Penilaian selektif kepada para calon debitur dan mengukur profitabilitas bagi pengembalian kreditur. Chapacity, Untuk mengetahui kemampuan nasabah untuk membayar kembali pembiayaan yang diterimanya. Dari penilaian ini terlihat kemampuan nasabah dalam mengelola bisnisnya. Capital, Penilaian yang dapat diberikan kepada calon debitur sesuai dengan kelayakan atas usaha yang akan atau sedang dilaksanakan. Condition of economy, keadaan usaha calon debitur yang berkaitan dengan peluang atau prospek usaha mereka dalam mengelola 
kredit. Collateral, adanya jaminan yang diberikan kepada pihak bank atau lembaga.

Penelitian ini sejalan dengan penelitian yang dilakukan oleh Fitri Susilawati tahun 2010 dimana dalam penelitian tersebut ditemukan bahwa Pembiayaan Mudharabah memiliki pengaruh positif terhadap peningkatan usaha. Jika semua karakteristik pembiayaan modal usaha yang terdiri dari tiga indikator yang diberikan oleh KSPP. Syariah BMT NU Jawa Timur dengan baik, maka akan mengalami peningkatan usaha nasabah dalam menggunakan produk pembiayaan mudharabah di KSPP. Syariah BMT NU Jawa Timur.

\section{Pembahasan Kedua \\ Seberapa Besar Kontribusi Pembiayaan Modal Usaha Terhadap Peningkatan Usaha Nasabah di KSPP. Syariah BMT NU Jawa Timur.}

Dari hasil nilai koefisien determinasi $\left(\mathrm{R}^{2}\right)$, dimana dalam tabel penelitian ini dilihat pada bagian $\mathrm{R}$ Square yaitu 0,655 atau $65,5 \%$. Hal ini berarti bahwa kontribusi variabel independen (Pembiayaan Modal Usaha) terhadap variabel dependen (Peningkatan Usaha Nasabah) pada KSPP.Syariah BMT NU Jawa Timur cukup besar, sedangkan sisanya $34,5 \%$ kemungkinan dipengaruhi atau dikontribusi oleh variabel-variabel lain yang tidak diikutkan oleh Pembiayaan Modal Usaha misalnya Pengetahuan Nasabah, Image/Citra Lembaga, Kualitas Pelayanan, Persepsi Masyarakat dan lain-lain.

\section{KESIMPULAN}

Berdasarkan hasil penelitian yang telah dilakukan mengenai Pengaruh Pembiayaan Modal Usaha Terhadap Peningkatan Usaha Nasabah di KSPP. Syariah BMT NU Jawa Timur yang telah di uraikan pada sebelumnya, maka peneliti dapat menarik beberapa kesimpulan sebagai berikut:

a. Pembiayaan Modal Usaha berpengaruh signifikan terhadap Peningkatan Usaha Nasabah di KSPP. Syariah BMT NU
Jawa Timur. Berdasarkan hasil uji t yaitu $t_{\text {hitung }} 7,909>\mathrm{t}_{\text {tabel }} 1,68957$ dengan taraf signifikan sebesar $0,000<0,05$. Nilai koefisien regresi $\mathrm{Y}=22,506+0,807 \mathrm{X}$ berarti variabel Pembiayaan Modal Usaha 0,807 bahwa jika terjadi peningkatan sebesar satu satuan pada variabel tersebut maka peningkatan usaha nasabah yang menggunakan produk pembiayaan Mudharabah di KSPP. Syariah BMT NU Jawa Timur meningkat sebesar 0,807 .

b. Kontribusi pembiayaan modal usaha terhadap peningkatan usaha nasabah yaitu sebesar $65,5 \%$ dan $34,5 \%$ sisanya dipengaruhi variabel lain yang tidak diikutkan dalam penelitian ini.

Berdasarkan kesimpulan diatas maka peneliti dapat memberikan beberapa saran yang mungkin bermanfaat kepada pihakpihak yang terkait. Saran yang dapat diberikan peneliti sebagai berikut:

a. Dalam menjalankan pembiayaan modal usaha KSPP. Syariah BMT NU Jawa Timur tetap menerapkan prinsip ta'awun (tolong-menolong) terhadap seluruh nasabah pembiayaan untuk mencapai kemajuan bersama.

b. Dalam menjalan usahanya, UKM diharapkan mampu menunjukkan transparansi keuntungan yang jelas kepada pihak KSPP. Syariah BMT NU Jawa Timur.

c. Penelitian selanjutnya dapat meneliti variabel yang berbeda yang lebih luas lagi dan pada subjek lain

\section{DAFTAR PUSTAKA}

Adiwarman, K. (2013). Bank Islam: Analisis Fiqih dan Keungan. Jakarta: PT. Raja Grafindo Persada.

Antonio, S. (2001). Bank Syariah: Dari Teori ke Praktik. Jakarta: Gema Insani.

Ayogi, V. D., \& Kurnia, T. (2015). Optimalisasi peran bmt dalam upaya penghapusan praktik rentenir. Jurnal Syarikah, 1(1), 1-16.

Bakhri, S., Leliya, \& Purnama, L. (2018). Tinjauan Etika Bisnis Islam Dalam 
Strategi Pemasaran Home Industri

Tahu Sari Rasa. Al-Mustashfa: Jurnal Penelitian Hukum Ekonomi Islam, Vol. 3, No, 285-299.

Damayanti, N. F., \& Herianingrum, S. (2014). Pengaruh Pembiayaan Dana Baitul Maal Wat Tamwil (BMT) Teladan Terhadap Kinerja Usaha Mikro Di Pasar Semolowaru Surabaya. JESTT, 1, 194-204. https://doi.org/10.16526/j.cnki.114762/tp.2014.11.051

Inayah, N., Kirya, I. K., \& Suwendra, I. W. (2014). Pengaruh Kredit Modal Kerja terhadap Pendapatan Bersih Usaha Kecil dan Menengah (UKM) Sektor Formal. Jurnal Manajemen Indonesia, 2(1).

Indrawan, R., \& Yaniawati, P. (2017). Metode Penelitian (Edisi Revi). PT. Refika Aditama.

Jati, D. S. E. (2015). Pengaruh Pemberian Kredit Modal Kerja Terhadap Tingkat Pendapatan Usaha Kecil Dan Menengah (UKM) Pada PT. Bank Pembiayaan Rakyat Syari'ah (BPRS) Margirizki Bahagia Bantul. UIN Sunan Kalijaga Yogyakarta.

Litriani, E., \& Levianadah, L. (2017). Pengaruh Pembiayaan Modal Kerja Terhadap Pendapatan Usaha Nasabah Pada PT. Bank Syariah Mandiri Kantor Cabang Simpang Patal Palembang. IFinance, 3(2), 123-140.

Malik, R., \& Siringoringo, H. (2007). Analisis Pengaruh Kredit, Aset Dan Jumlah Pegawai Terhadap Pendapatan Usaha Kecil Menengah (UKM) Penerima Kredit Bank Perkreditan Rakyat. Jurnal Ekonomi Universitas Gunadarma, (September).

Muhammad. (2005). Manajemen Pembiayaan Bank Syariah. Yogyakarta: UPP AMP YKPN.

Suryani, \& Hendryadi. (2018). Metode Riset Kuantitatif (Cetakan ke). Jakarta: Prenamedia Group. 